\title{
SISTEM E-RECRUITMENT KARYAWAN BERBASIS WEB
}

\author{
${ }^{1}$ Silvia Dina Sari \\ ${ }^{2}$ Silvia Ratna \\ Fakultas Teknologi Informasi, Universitas Islam Kalimantan \\ Muhammad Arsyad Al Banjari Banjarmasin \\ Email : dinasari@gmail.com \\ Fakultas Teknologi Informasi, Universitas Islam Kalimantan \\ Muhammad Arsyad Al Banjari Banjarmasin \\ Email : via.Borneo@gmail.com
}

\begin{abstract}
ABSTRAK
Pada saat ini Bank Kalsel Syariah belum memiliki sistem penerimaan pegawai baru sendiri, masih menerima pegawai baru sistem penerimaan pegawai baru dari Bank Kalsel Konvensional dan sistem penerimaan pegawai baru yang digunakan masih berbasis manual.

Perkembangan zaman semakin maju maka teknologi menjadi semakin canggih, manusia mampu menciptakan sarana-sarana untuk mempermudah pengelolaan sistem informasi seperti menggunakan sistem komputerisasi yang mulai banyak digunakan, maka pengguna akan mengelola data pelamar dengan cepat, mudah, lebih aman hingga data tersimpan. Karena proses manual dianggap kurang efektif dan efesien dalam proses pengolahan data pelamar.

Dengan menggunakan sistem pengembang aplikasi menggunakan bahasa pemrograman $P H P$ Hypertext Preprocessor (PHP) dan database yang digunakan adalah database MySQL bertujuan agar pengguna mampu menggunakan sistem ini secara baik dan memanfaatkannya secara maksimal sehingga penyajian informasi recruitment menjadi lebih efektif dan efisien.
\end{abstract}

Kata Kunci: Manual, PHP Hypertext Preprocessor (PHP), MySQL, database, recruitment

\section{PENDAHULUAN}

Bank Kalsel Syariah Banjarmasin yang berkantor berada di Jalan S. Parman RT. 03 Kecamatan Banjarmasin Tengah Kota Banjarmasin merupakan Badan Usaha Milik Daerah yang memberikan pelayanan perbankan kepada masyarakat Kalimantan Selatan yang mayoritas beragama Islam. Antusias masyarakat Kalimantan Selatan terhadap Bank Kalsel Syariah mulai meningkat karena nasabah bank konvensional mulai beralih ke bank syariah yang menjalankan prinsip bagi hasil sesuai dengan kaidah ajaran agama Islam mengenai hukum riba. Bank Kalsel Syariah mempersiapkan dan melakukan pengelolaan sumber daya manusia yang memiliki kemampuan dalam membangun dan mengembangkan ekonomi syariah di masa akan datang.
Pada saat ini Bank Kalsel Syariah belum memiliki sistem penerimaan pegawai baru sendiri, masih menerima pegawai baru sistem penerimaan pegawai baru dari Bank Kalsel Konvensional dan sistem penerimaan pegawai baru yang digunakan masih berbasis manual. Sistem manual ini memiliki kelemahan seperti menerima berkas lamaran pekerjaan yang dikirimkan pelamar. Kemudian divisi sumber daya manusia menerima berkas lamaran pekerjaan dan melakukan pencatatan dalam buku registrasi pelamar sebagai arsip lalu dikumpulkan dalam pengarsipan. eterlambatan harus mencari terlebih dahulu dalam pencarian data pelamar dibuku registrasi pelamar dan berkas lamaran dalam pengarsipan. Karena penyimpanan data pelamar hanya ada dalam buku registrasi pelamar. Perkembangan zaman semakin maju maka teknologi menjadi semakin canggih, manusia mampu menciptakan sarana- 
sarana untuk mempermudah pengelolaan sistem informasi seperti menggunakan sistem komputerisasi yang mulai banyak digunakan, maka pengguna akan mengelola data pelamar dengan cepat, mudah, lebih aman hingga data tersimpan. Karena proses manual dianggap kurang efektif dan efesien dalam proses pengolahan data pelamar.

Berdasarkan permasalahan diatas, Bank Kalsel Syariah memerlukan sistem penerimaan pegawai baru berbasis website dimana media pengumpulan data pelamar dapat dilakukan secara komputerisasi. Bank Kalsel Syariah memiliki perangkat yang memadai untuk melaksanakan sistem komputerisasi pada penerimaan pegawai baru berbasis website. Sehingga dapat membantu Bank Kalsel Syariah dalam proses pendataan pelamar menjadi lebih efektif dan efisien.

Dalam rangka meningkatkan kualitas proses penerimaan pegawai baru pada Bank Kalsel Syariah maka disusunlah Penelitian ini dengan Judul "SISTEM E-RECRUITMENT KARYAWAN BERBASIS WEB ".

\section{LANDASAN TEORI}

\section{Pengertian Aplikasi}

Menurut (Hartono, Analisa dan Desain Sistem Informasi: Pendekatan Terstruktur Teori dan Praktik Aplikasi Bisnis, 2005), aplikasi adalah penggunaan dalam suatu komputer, instruksi (instruction) atau pernyataan (statement) yang disusun sedemikian rupa sehingga komputer dapat memproses input menjadi output.

Aplikasi berasal dari kata application yang artinya penerapan, lamaran, penggunaan. Secara istilah aplikasi adalah program siap pakai yang direkam untuk melaksanakan suatu fungsi bagi pengguna atau aplikasi yang lain dan dapat digunakan oleh sasaran yang dituju (totalinfo) (www.totalinfo.or.id)

\section{Pengertian Penerimaan Pegawai Baru}

Penerimaan pegawai baru adalah dimana perusahaan yang sedang berkembang memerlukan pegawai tambahan maka dilakukan serangkaian proses pemilihan para pelamar, calon pegawai hingga menjadi pegawai secara tepat, cepat dan akurat.

\section{Pengertian Sistem}

Menurut (Wahyono, Sistem Informasi, Konsep Dasar, Analisa Desain, dan Implementasi, 2004), sistem merupakan suatu group dari elemen-elemen baik yang berbentuk fisik maupun nonfisik yang merupakan suatu kumpulan dan saling berhubungan diantaranya dan berinteraksi bersama-sama menuju satu atau tujuan, sasaran atau akhir dari sebuah sistem.

\section{Pengertian E-Recruitment}

Menurut (Harris, 2007), Online Recruitment adalah penarikan pegawai menggunakan internet atau dunia maya dalam proses perekrutannya untuk mencari orang yang mampu bertanggung jawab dalam pekerjaannya. Kelebihan dan kekurangan menggunakan sistem online recruitment, yaitu :

1. Kelebihan Media Online Recruitment :

a) Mudah dan Praktis

Anda hanya perlu menjadi member disalah satu situs lowongan kerja/online rekrutmen. Kemudian anda mendapatkan info lowongan kerja dan melamar dari situs tersebut.

b) Proses yang Cepat

Bandingkan ketika Anda mengirimkan lamaran kerja melalui pos paling tidak 3-7 hari baru diterima oleh perusahaan yang dituju. Sedangkan melalui media online Anda hanya duduk di depan komputer dan butuh waktu 5-10 menit untuk CV anda diterima oleh HRD perusahaan.

c) Hemat Biaya

Anda tidak perlu mengeluarkan uang untuk print/photo copy ijazah, beli amplop dan membayar jasa pengiriman seperti yang anda lakukan jika Anda mengirim lamaran via pos.

2. Kekurangan Media Online Recruitment :

a) Lowongan Fiktif, banyaknya iklan lowongan kerja yang tidak mencantumkan perusahaan yang jelas, atau yang tidak memiliki ijin usaha resmi dengan tujuan untuk mencari keuntungan dari pencari kerja dengan berbagai cara seperti menarik 
bayaran dan menawarkan lowongan pekerjaan yang sebenarnya tidak ada.

b) Kerahasiaan, adanya penyalahgunaan data $\mathrm{CV}$ yang digunakan oleh pihak tertentu untuk menawarkan barang atau jasa.

\section{Sistem Informasi}

Menurut Robert A. Leitch dan K. Roscoe Davis, tahun 1983 pengertian sistem informasi dalam (Hartono, Sistem Teknologi Informasi, 2005), sistem informasi adalah suatu sistem di dalam suatu organisasi yang mempertemukan kebutuhan pengolahan transaksi harian, mendukung operasi, bersifat manajerial dan kegiatan strategi dari suatu organisasi dan menyediakan pihak luar tertentu dengan laporan-laporan yang diperlukan. Untuk membuat suatu sistem informasi, maka diperlukan analisis untuk menentukan kebutuhan apa saja yang akan dijadikan sumber informasi oleh sistem.

\section{Unified Modelling Language (UML)}

Menurut (Nugroho, Rekayasa Perangkat Lunak Menggunakan UML dan Java, 2010), UML (Unified Modeling Language) adalah 'bahasa' pemodelan untuk sistem atau perangkat lunak yang berparadigma 'berorientasi objek'. Pemodelan (modeling) sesungguhnya digunakan untuk penyederhanaan permasalahan-permasalahan yang kompleks sedemikian rupa sehingga lebih mudah dipelajari dan dipahami.

Menurut (Nugroho, Rekayasa Perangkat Lunak Menggunakan UML dan Java, 2009), UML (Unified Modeling Language) adalah metodologi kolaborasi antara metoda-metoda Booch, OMT (Object Modeling Technique), serta OOSE (Object Oriented Software Enggineering) dan beberapa metoda lainnya, merupakan metodologi yang paling sering digunakan saat ini untuk analisa dan perancangan sistem dengan metodologi berorientasi objek mengadaptasi maraknya penggunaan bahasa pemrograman berorientasi objek (OOP).

Berdasarkan pendapat yang dikemukakan di atas dapat ditarik kesimpulan bahwa Unified Modelling Language (UML) adalah sebuah bahasa yang berdasarkan grafik atau gambar untuk menvisualisasikan, menspesifikasikan, membangun dan pendokumentasian dari sebuah sistem pengembangan perangkat lunak berbasis Objek (Object Oriented programming). Unified Modeling Language (UML) muncul karena adanya kebutuhan pemodelan visual untuk menspesifikasikan, menggambarkan, membangun dan dokumentasi dari sistem perangkat lunak. Unified Modeling Language (UML) merupakan bahasa visual untuk pemodelan dan komunikasi mengenai sebuah sistem dengan menggunakan diagram dan teksteks pendukung.

Jenis-jenis diagram Unified Modeling Language (UML) Menurut (Henderi, 2008), Berikut ini adalah definisi mengenai 5 diagram Unified Modeling Language (UML):

1. Use Case Diagram secara grafis menggambarkan interaksi antara sistem, sistem eksternal dan pengguna. Dengan kata lain use case diagram secara grafis mendePenelitiankan siapa yang akan menggunakan sistem dan dalam cara apa pengguna (user) mengharapkan interaksi dengan sistem itu. Use case secara naratif digunakan untuk secara tekstual menggambarkan sekuensi langkah-langkah dari setiap interaksi.

2. Class Diagram menggambarkan struktur object sistem. Diagram ini menunjukkan class object yang menyusun sistem dan juga hubungan antara class object tersebut.

3. Sequence Diagram secara grafis menggambarkan bagaimana objek berinteraksi dengan satu sama lain melalui pesan pada sekuensi sebuah use case atau operasi.

4. State Chart Diagram digunakan untuk memodelkan behaviour objek khusus yang dinamis. Diagram ini mengilustrasikan siklus hidup objek berbagai keadaan yang dapat diasumsikan oleh objek dan eventevent (kejadian) yang menyebabkan objek beralih dari satu state ke state yang lain.

5. Activity Diagram secara grafis digunakan untuk menggambarkan rangkaian aliran aktivitas baik proses bisnis maupun use case. Activity diagram dapat juga digunakan untuk memodelkan action yang akan dilakukan saat sebuah operasi dieksekusi, dan memodelkan hasil dari action tersebut 


\section{Web Server}

Server atau Web server adalah sebuah software yang memberikan layanan berbasis data dan berfungsi menerima permintaan dari HTTP atau HTTPS pada klien yang dikenal dan biasanya kita kenal dengan nama web browser (Mozilla Firefox, Google Chrome) dan untuk mengirimkan kembali yang hasilnya dalam bentuk beberapa halaman web dan pada umumnya akan berbentuk dokumen HTML. (https://idcloudhost.com/pengertian-webserver-dan-fungsinya/ diakses 1 November 2016).

\section{METODE PENELITIAN}

\section{Analisis Sistem}

Penerimaan pegawai baru pada Bank Kalsel Syariah yang berjalan sampai saat ini hanya menggunakan sistem manual, yaitu pelamar diharuskan mengirim berkas lamaran ke Bank Kalsel Konvensional. Setelah berkas lamaran diterima maka divisi sumber daya manusia melakukan pengkualifikasian berkas lamaran yang sudah ditentukan. Divisi sumber daya manusia akan memanggil pelamar sesuai kebutuhan. Jika pelamar belum dibutuhkan maka pelamar akan masuk daftar tunggu.

Pelamar sesuai klasifikasi kebutuhan Bank Kalsel Konvensional, dipanggil divisi sumber daya manusia untuk mengikuti beberapa tes dalam proses penerimaan pegawai baru antara lain tes wawancara awal, tes potensi akademik, tes psikotes, tes kesehatan, dan tes wawancara akhir. Pada setiap tes tersebut menggunakan sistem gugur jika gagal calon pegawai tidak dapat melanjutkan tes. Para calon pegawai yang lulus mengikuti seluruh tes akan mengikuti OJT (On Job Training) setelah itu divisi sumber daya manusia melakukan penempatan, salah satunya Bank Kalsel Syariah.

\section{Flowchart Sistem Lama}

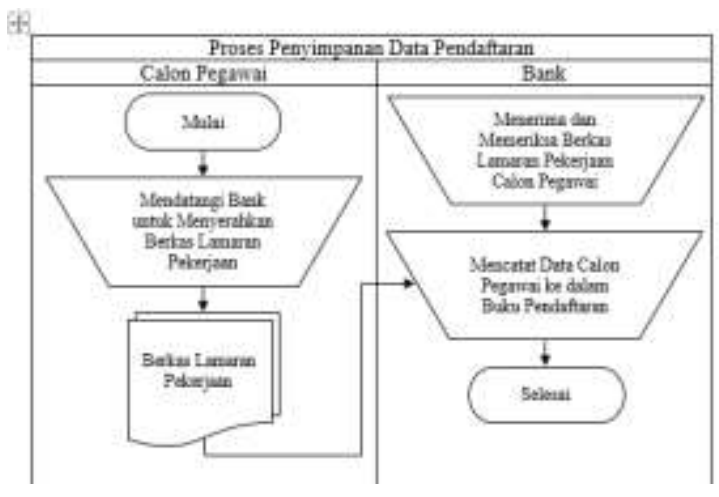

Alur Proses Tes Potensi Akademik dan Perbankan

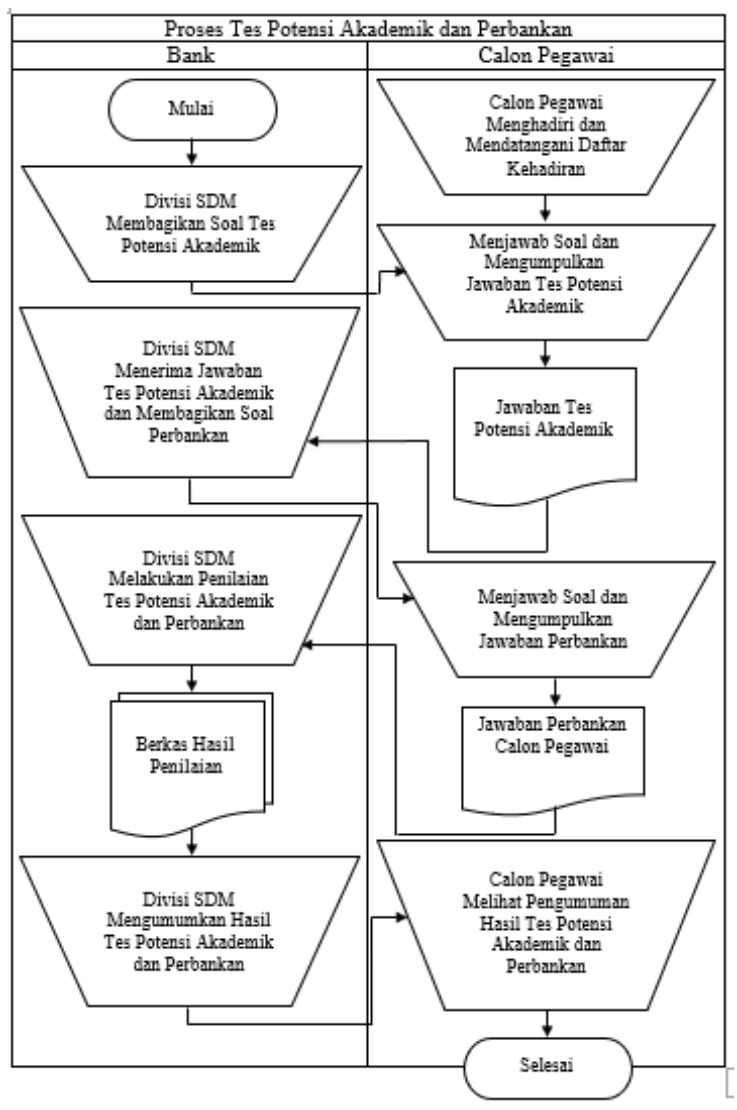


Alur Proses Tes Wawancara Akhir

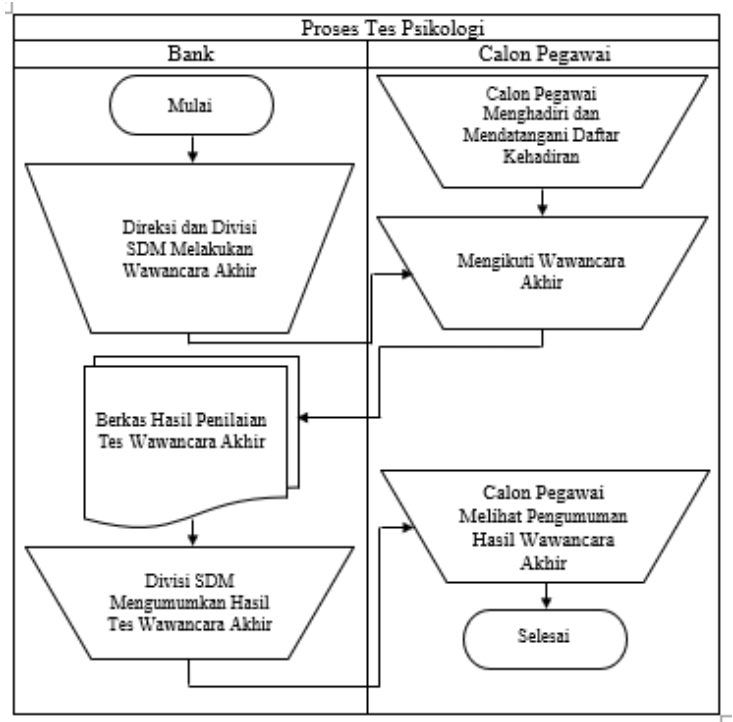

\section{Diagram Konteks}

Menurut (Kristanto, Perancangan Sistem Informasi dan Aplikasinya, 2008), Diagram konteks adalah sebuah diagram yang menggambarkan hubungan antara entiti luar, masukan dan keluaran dari sistem.

Berikut ini adalah rancangan diagram konteks yang didesain oleh penulis dalam pembuatan sebuah Sistem E-Recruitment Karyawan Berbasis Web :

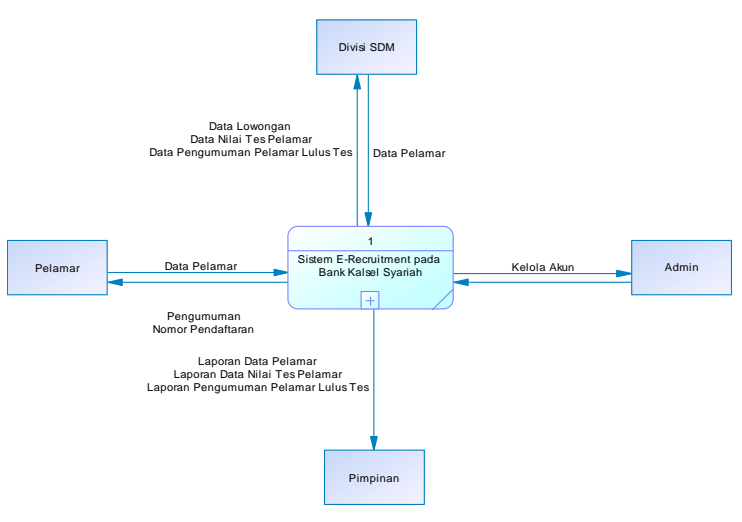

\section{Data Flow Diagram (DFD)}

Menurut (Kristanto, Perancangan Sistem Informasi dan Aplikasinya, 2008), Data Flow Diagram (DFD) adalah suatu model logika data atau proses yang dibuat untuk menggambarkan darimana asal data dan kemana tujuan data yang keluar dari sistem, dimana data disimpan, proses apa yang menghasilkan data tersebut dan interaksi antara data yang tersimpan dan proses yang dikenakan pada data tersebut.

Berikut ini adalah rancangan Data Flow Diagram (DFD) yang didesain oleh penulis dalam pembuatan sebuah Sistem E-Recruitment Karyawan Berbasis Web :

\section{DFD Level 0}

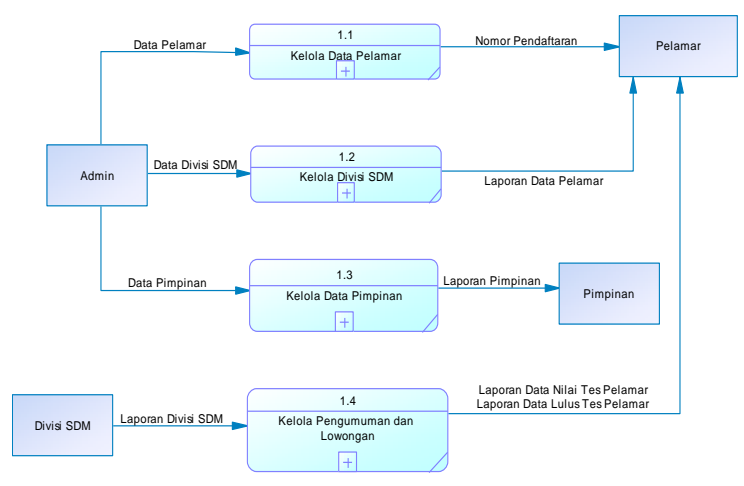

DFD Level 1 (Proses Pelamar)

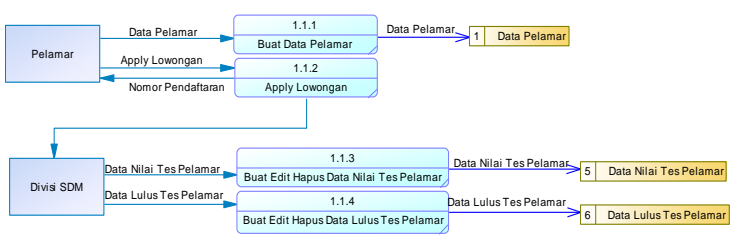

Tampilan Aplikasi

Halaman Antarmuka Halaman Utama

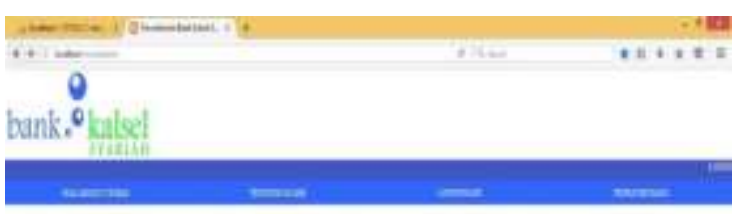

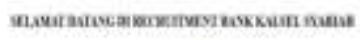

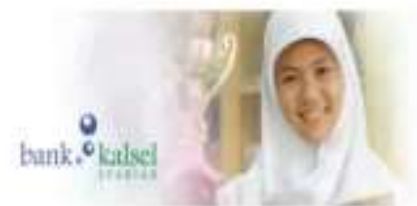


Halaman Antarmuka Pendaftaran
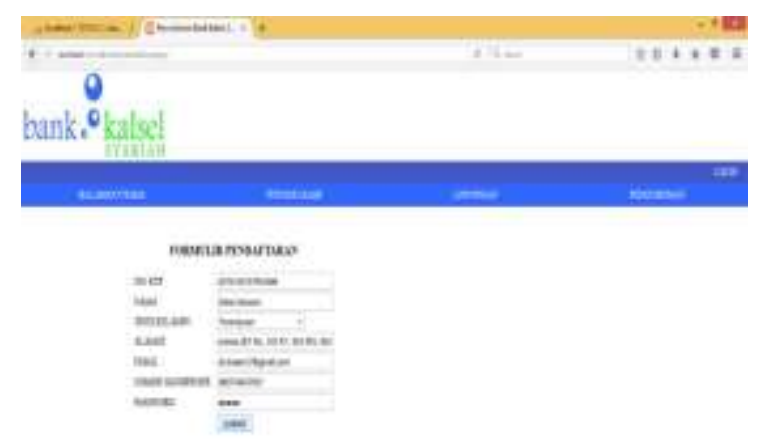

Halaman Antarmuka Halaman Utama Pelamar

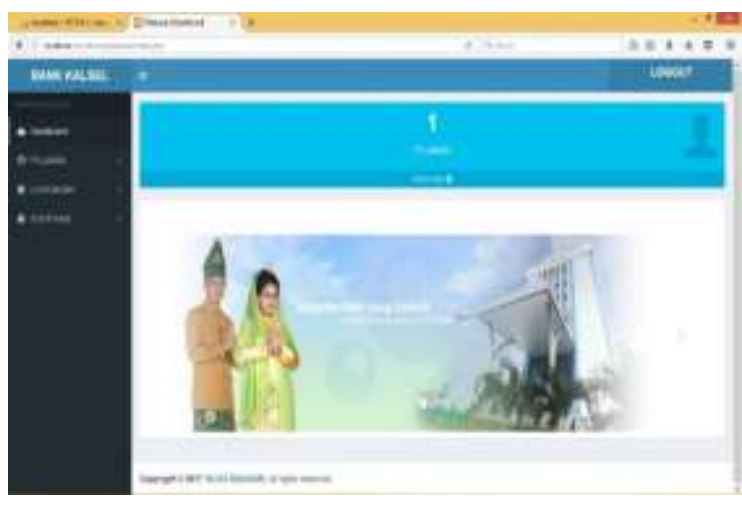

Halaman Antarmuka Pelamar

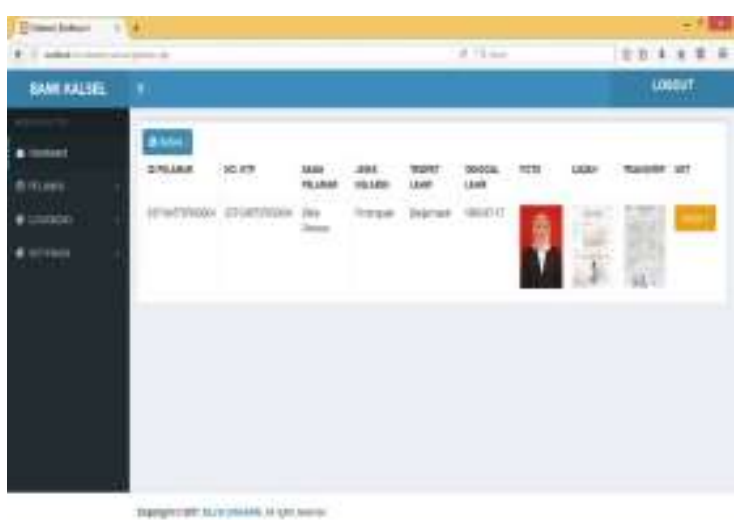

Halaman Antarmuka Tes Potensi Akademik

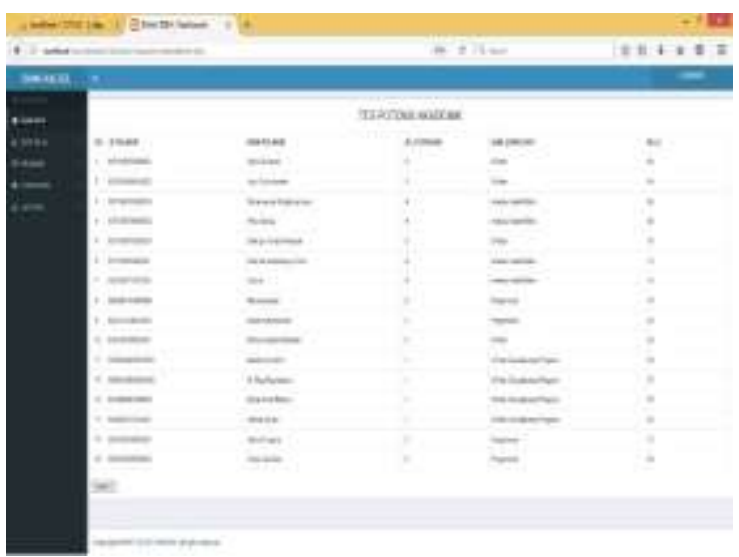

Halaman Antarmuka Wawancara Akhir

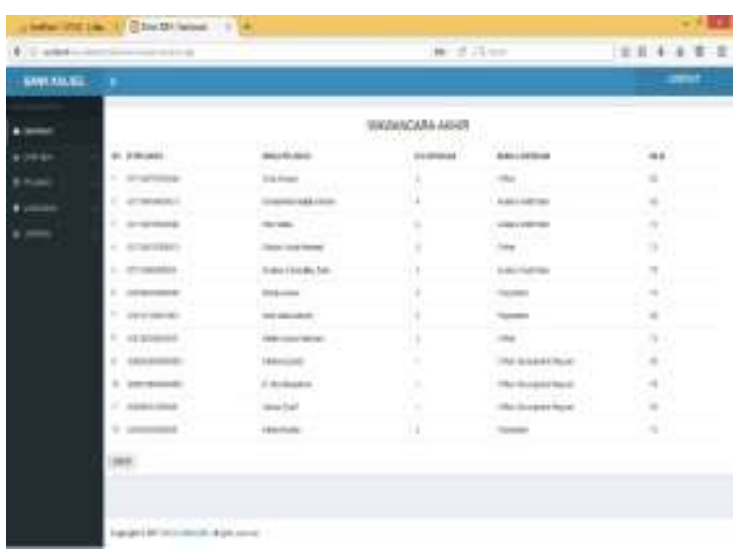

Halaman Antarmuka Laporan Data Pelamar

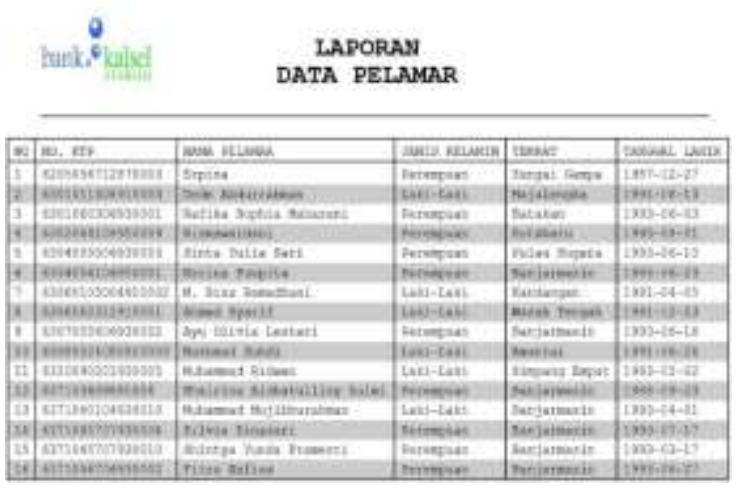


Halaman Antarmuka Laporan Wawancara Awal
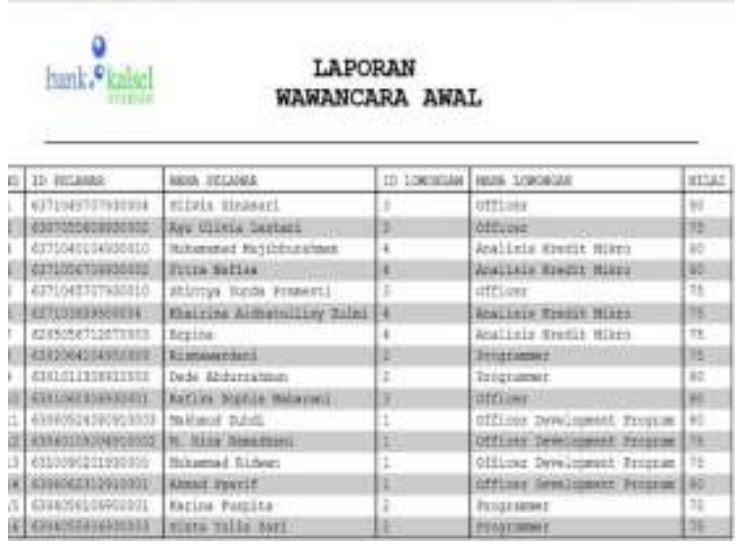

Halaman Antarmuka Laporan Tes Potensi Akademik
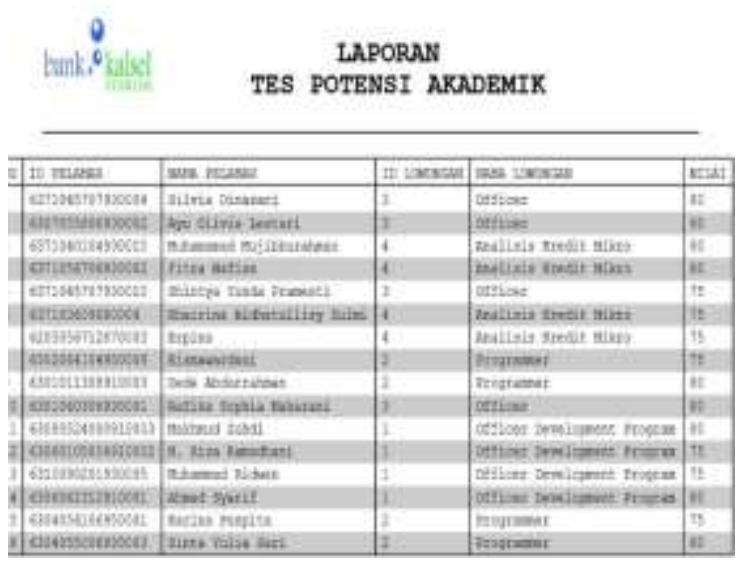

Halaman Antarmuka Laporan Wawancara Akhir

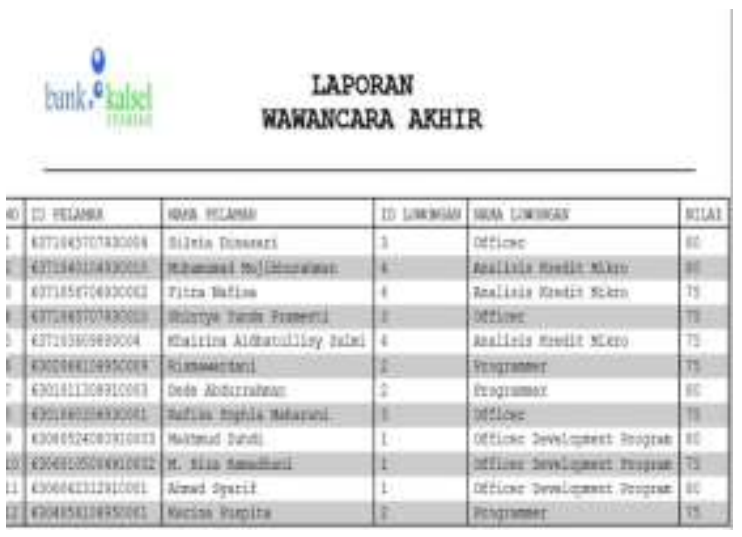

Halaman Antarmuka Laporan Hasil Seleksi

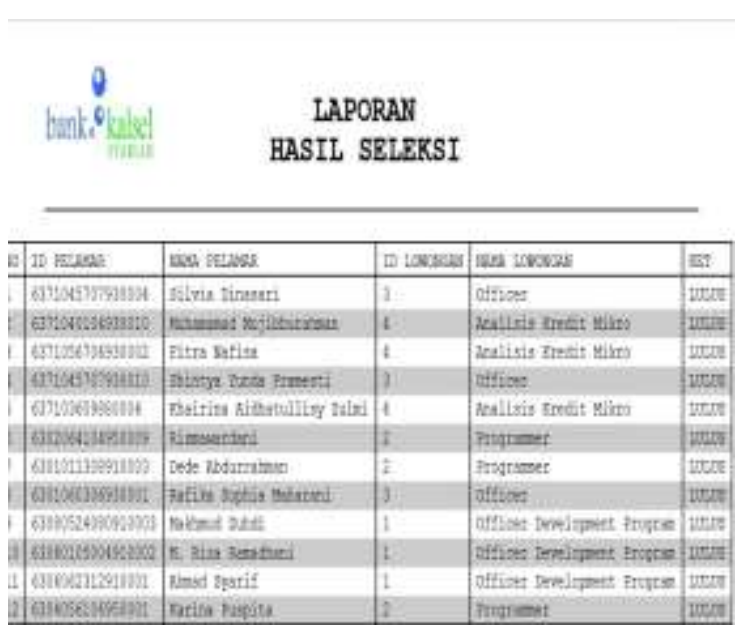

\section{KESIMPULAN}

Berdasarkan dari pembahasanpembahasan sebelumnya dari Penelitian ini maka dapat ditarik beberapa kesimpulan antara lain :

1. Aplikasi E-Recruitment pada Bank Kalsel Syariah dapat diaplikasikan langsung pada komputer.

2. Aplikasi E-Recruitment pada Bank Kalsel Syariah mempermudah pengelolaan data pelamar, meningkatkan reliabilitas data, mempersingkat waktu pendataan dan waktu pencarian data.

3. Aplikasi E-Recruitment pada Bank Kalsel Syariah lebih terorganisir dengan baik dari sebelumnya yang belum ada sama sekali.

\section{DAFTAR PUSTAKA}

Al Fatta, Hanif. (2007). Analisis \& Perancangan Sistem Informasi untuk Keunggulan Bersaing Perusahaan \& Organisasi Modern. Yogyakarta: Andi.

Arief, M. Rudyanto. (2011). Pemrograman Web Dinamis menggunakan PHP dan MySQL. Yogyakarta: Andi.

Arbie. (2004). Manajemen Data Base Dengan My SQL. Yogyakarta: Andi.

Astamal, Rio. (2006). Mastering Kode HTML. Surabaya: Linux User Group STIKOM.

Hartono, Jogiyanto. (2005). Analisa dan Desain Sistem Informasi: Pendekatan Terstruktur Teori dan Praktik Aplikasi Bisnis. Yogyakarta: Andi. 
Hartono, Jogiyanto. (2005). Sistem Teknologi Informasi. Yogyakarta: Andi.

Henderi. (2008). Unified Modelling Language. Tangerang: Raharja Enrichment Centre (REC).

Sommerville, Ian. ( 2011). Software Engineering (Rekayasa Perangkat Lunak). Jakarta: Erlangga

Kadir, Abdul. (2003). Pengenalan Sistem Informasi. Yogyakarta: Andi.

Kadir, Abdul . (2008). Tuntunan Praktis Belajar Database Menggunakan MySQL. Yogyakarta: Andi.

Kristanto, Andri. (2008). Perancangan Sistem Informasi dan Aplikasinya. Yogyakarta: Gava Media

Madcoms. (2009). Menguasai XHTML, CSS, PHP \& MySQL melalui Dreamweaver. Yogyakarta: Andi.

Nugroho, Adi. (2010). Rekayasa Perangkat Lunak Menggunakan UML dan Java. Yogyakarta: Andi.

Nugroho, Adi. (2009). Rekayasa Perangkat Lunak Menggunakan UML Dan Java. Yogyakarta: Andi.

Rachmawati, Ike Kusdyah. (2008). Manajemen Sumber Daya Manusia. Yogyakarta: Andi.

Rivai, Veithzal. (2006). Manajemen Sumber Daya Manusia untuk Perusahaan: dari
Teori ke Praktik. Jakarta: PT Raja Grafindo Persada.

Samsuddin, Sadili. (2006). Manajemen Sumber Daya Manusia. Bandung: Pustaka Setia.

Siagian, Sondang P. (2011). Manajemen Sumber Daya Manusia. Jakarta: PT. Bumi Aksara.

Simamora, Henry. (1995). Manajemen Sumber Daya Manusia. Jakarta: STIE YKPN.

Sofyandi, Herman. (2008). Manajemen Sumber Daya Manusia. Yogyakarta: Graha Ilmu.

Teguh, Wahyono. (2004). Sistem Informasi, Konsep Dasar, Analisa Desain, dan Implementasi. Yogyakarta: Graha Ilmu.

Yeni Kustiyahningsih, Devie Rosa Anamisa. (2011). Pemograman Basis Data Berbasis Web Menggunakan PHP \& MySQL. Yogyakarta: Graha Ilmu.

http://bankkalsel.co.id diakses tanggal 1 November 2016

http://google.com/2011/07/pengertian-dasarcss.html diakses 1 November 2016

https://idcloudhost.com/pengertian-webserver-dan-fungsinya/ diakses 1 November 2016

https://id.wikipedia.org/wiki/Adobe_Dreamwe aver diakses 1 November 2016 